Шульжик Юрій Олександрович кандидат технічних. наук, професор кафедри економіки та менеджменту, Прикарпатський інститут ім. М.Грушевського, вул. Володимира Івасюка, 21, Трускавець, 82200, тел.: (096) 350-23-10, e-mail: pimaup_doctorant@ukr.net, https://orcid.org/0000-0003-1699-054X

Сенишин Світлана Свгенівна директор. Прикарпатський інститут ім. М.Грушевського, вул. Володимира Івасюка, 21, Трускавець, 82200, тел.: (067) 148-05-49, e-mail: pimaup_doctorant@ukr.net, https://orcid.org/0000-0002-7905-3062

Пелещишин Ростислав Миколайович кандидат педагогічних наук, директор, СЗШ № 54, вул. Миколи Хвильового, 16, м. Львів, 79000, тел.: (096) 742-37-21, e-mail: rostislavpele@gmail.com, https://orcid.org/0000-0002-7196-2341

\title{
ПЕРЕВАГИ ТА НЕДОЛІКИ ОН-ЛАЙН НАВЧАННЯ В ПЕРІОД ПАНДЕМІЇ COVID-19
}

Анотація. В науковій статті досліджено та проаналізовано особливості онлайн навчання в період коронавірусної пандемії. Оскільки ситуація з тривалістю карантинних обмежень зумовила активізацію самостійного навчання студентів, то взаємодія між учителем і учнем чи студентом і викладачем стала відбуватися віртуально за допомогою системи Інтернет. У цьому зв'язку поширення COVID19 викликало нагальну необхідність дослідження і вивчення можливостей дистанційного навчання та інноваційних освітніх технологій 3 метою їх запровадження в навчальний процес. Наголошено, що в даний час значний обсяг досліджень присвячений змінам на ринку праці та необхідності адаптації до цих змін у вищій освіті. Виокремлено переваги та недоліки он-лайн навчання. На основі проведених онлайн опитувань встановлено, що для $37 \%$ навчальних закладів дистанційне навчання було проблемою, оскільки вони раніше не мали та кого досвіду, тому не були готові до навчання під час карантину. Доведено, що в починаючи з березня 2020 року з поширенням пандемії коронавірусу COVID-19 та обмежених карантинних заходів основним варіантом набуття знань та організації навчального процесу у всіх закладах освіти виступає дистанційне навчання, як сукупність технологій, які забезпечують учнів та студентів основною частиною освітніх матеріалів, а інтерактивна взаємодія учнів та вчителів, студентів та викладачів в процесі навчання забезпечують широкі можливості самостійної роботи з освітніми матеріалами в процесі вивчення тієї чи іншої дисципліни. Доведено перспективність та доцільність перетворення документів в доступні до перегляду в Інтернеті оскільки користувальницькі інтерфейси сприяють отриманню доступу до оцифрованих матеріалів, $\epsilon$ «найслабшим місцем» у сфері масової оцифровки текстів. Акцентована увага на 
важливій ролі програмного забезпечення користувацького інтерфейсу, оскільки зростає роль і значення цифровізації в освіті та усіх галузях суспільного життя загалом.

Ключові слова: он-лайн навчання; пандемія коронавірусу COVID-19; дистанційне навчання; дистанційна освіта; цифровізація освіти; дистанційний режим навчання.

Shulzhyk Yurii Oleksandrovych Ph.D., Professor of the Department of management of organizations, economics and entrepreneurship, Precarpathian Institute named of Mykhailo Hrushevsky of Interregional Academy of Personnel Management, Volodymyra Ivasyuka St., 21, Truskavets, 82200, tel.: (096) 350-23-10, e-mail: pimaup_doctorant@ukr.net, https://0000-0003-1699-054X

Senyshyn Svitlana Yevhenivna Director, Precarpathian Institute named of Mykhailo Hrushevsky of Interregional Academy of Personnel Management, Volodymyra Ivasyuka St., 21, Truskavets, 82200, tel.: (067) 148-05-49, e-mail: pimaup_doctorant@ukr.net, https://orcid.org/0000-0002-7905-3062

Peleschyshyn Rostyslav Миколайович Candidate of Pedagogical Sciences, Director, Secondary School №54 Lviv, Mykola Khvylovy St., 16, Lviv, 79000, tel.: (096) 742-37-21, e-mail: rostislavpele@gmail.com, https://orcid.org/00000002-7196-2341

\section{ADVANTAGES AND DISADVANTAGES OF ONLINE STUDY DURING THE COWID-19 PANDEMIC}

Abstract. The scientific article investigates and analyzes the features of online learning during the coronavirus pandemic. As the situation with the duration of quarantine restrictions led to the intensification of independent learning of students, the interaction between teacher and student or student and teacher began to take place virtually via the Internet. In this regard, the spread of COVID-19 has necessitated the study and study of distance learning opportunities and innovative educational technologies in order to implement them in the educational process. It is emphasized that currently a significant amount of research is devoted to changes in the labor market and the need to adapt to these changes in higher education. The advantages and disadvantages of online learning are highlighted. Based on online surveys, $37 \%$ of educational institutions found that distance learning was a problem because they did not have such experience before, so they were not ready to learn during quarantine. It has been proven that since March 2020, with the spread of the COVID-19 coronavirus pandemic and limited quarantine measures, the main option for acquiring knowledge and organizing the educational process in all educational institutions is distance learning, as a set of technologies that provide students with basic educational materials. and interactive interaction of pupils and teachers, students and teachers in the course of training provide wide possibilities of independent work with educational materials in 
the course of studying of this or that discipline.The prospects and expediency of making documents available for viewing on the Internet have been proved, as user interfaces facilitate access to digitized materials and are the "weakest point" in the field of mass digitization of texts. Emphasis is placed on the important role of user interface software, as the role and importance of digitalization in education and all spheres of public life in general is growing.

Keywords: online learning; the COVID-19 coronavirus pandemic; Distance Learning; distance education; digitalization of education; distance learning mode.

Постановка проблеми. Маючи понад 27,2 мільйона випадків коронавірусу та понад 900 тисяч смертей по всьому світу, люди почали вживати серйозних запобіжних заходів, використовуючи засоби он-лайн. Люди не готові повернутися до своїх робочих місць та відновити роботу з офісу, оскільки ця пандемія COVID-19 потрясла довіру людей. Головне завдання, яке постало щодо нових реалій он-лайн навчання не лише в Україні, а й у цілому світі, полягає у тому, як саме такий підхід змінить якість освіти : на краще чи на гірше. I загалом, яких трансформацій зазнає вся система освіти в Ук раїні та у світі, оскільки несподівана пандемія внесла свої корективи в діяльність освітньої галузі. Наголошено, що з 12 березня 2020 року традиційна освіта стала неможливою у зв'язку із поширенням коронавірусу COVID-19. Тому Кабінет Міністрів України видав Постанову № 211 від 11.03 .2020 р. «Про запобігання поширенню на території України короно вірусу COVID-19», Міністерство освіти і науки України розробило ряд нормативних документів 3 метою організації освітнього процесу під час карантину, а саме: наказ № 392 від 12.03.20 р. «Про забезпечення виконання профілактичних i протиепідемічних заходів». Керуючись вищезазначеними нормативно-правовими документами, університети України почали здійснювати навчання в дистанційному режимі, зокрема 3 використанням платформи Moodle, Google Class, месенжер, Viber, електронну пошту, телефонний зв'язок чи в режимі Zoom.

Освітянам довелося в авральному режимі налаштовувати навчальний процес. У цьому зв’язку вважаємо актуальним висвітлити переваги та недоліки он-лайн навчання в нинішніх умовах пандемії COVID-19. Наголошено, що в Україні ще недостатньо практичних та методичних рекомендації щодо ефективної організації занять в умовах дистанційного навчання, а також інструментів, за допомогою яких вчителі та викладачі мали б змогу обмінюватися набутим позитивним досвідом одні 3 одними. Наведено сутнісні ознаки та відмінності в поняттях «дистанційне навчання» та «дистанційна освіта».

Аналіз останніх досліджень і публікацій. Дослідження науковців Якуба, Бернса, Фарабосі, Ортеги, Пейро та Саксени ще у 2005 році довели перспективність та доцільність перетворення документів в доступні до перегляду в Інтернеті. Койл (2006) вважає, що користувальницькі інтерфейси, що дозволяють отримати доступ до оцифрованих матеріалів, $\epsilon$ «найслабшим місцем» у сфері масової оцифровки текстів. Результатом вдосконалення має стати швидший та більш точний перехід оцифрованих матеріалів до остаточних версій, 
оприлюднених для широкого кола користувачів. Особливої актуальності набули ці наукові твердження у теперішній час коли усі навчальні заклади усіх рівнів та форм власності навчальний процес перевели на он-лайн режим навчання. Проте, на даний час недостатньо грунтовних досліджень стосовно запровадження обов'язкових форм дистанційного навчання та життя громадян в умовах карантину в Україні. Проведені онлайн-опитування свідчать, що для $37 \%$ навчальних закладів дистанційне навчання стало проблемою, оскільки вони раніше не мали такого досвіду, тому не були готові до навчання під час карантину.

Мета статті - дослідити та проаналізувати переваги та недоліки он-лайн навчання в період пандемії коронавірусу COVID-19.

Виклад основного матеріалу. Актуальність теми зумовлена впровадженням інноваційних технологій в організацію освітнього процесу у зв'язку із поширенням коронавірусу COVID-19. Донині поняття «дистанційна освіта» та «дистанційне навчання» вживалося тоді, коли хотіли розширити можливості i надати освітні послуги усім бажаючим, модернізувати систему освіти, створити умови для особистісного розвитку особистості, підвищення якості i конкурентоспроможності освіти та ін. На сучасному етапі ці поняття дають єдину можливість здобути освіту.

В умовах пандемії коронавірусу COVID-19 та обмежених карантинних заходів поширеним варіантом набуття знань та організації навчального процесу у всіх закладах освіти виступає дистанційне навчання, тобто сукупність технологій, які забезпечують учнів та студентів основною частиною освітніх матеріалів, а інтерактивна взаємодія учнів та вчителів, студентів та викладачів в процесі навчання забезпечують широкі можливості самостійної роботи 3 освітніми матеріалами в процесі вивчення тієї чи іншої дисципліни.

Дистанційне навчання передбачає взаємодію 4 типів учасників: учень / студент, репетитор (репетитор, інструктор, вчитель, викладач), організатор (плани та координатори освітньої діяльності) та адміністратор (забезпечує стабільну роботу системи, вирішує технічні проблеми, моніторить статистику системи). Вимушений перехід на дистанційне навчання 312 березня 2020 року вимагає перегляду та модифікації методологічних категорій: педагогічна теорія, педагогічна концепція, педагогічна ідея, педагогічна закономірність та педагогічні принципи. Ситуація 3 тривалістю карантинних обмежень зумовила активізацію самостійного навчання студентів, коли взаємодія між учителем i учнем чи студентом і викладачем відбувається віртуально за допомогою системи Інтернет. Поширення COVID-19 викликало нагальну необхідність дослідження і вивчення можливостей дистанційного навчання та інноваційних освітніх технологій з метою їх запровадження в навчальний процес.

Практика показує, що навчання під час карантину ще з весни 2020 року було доволі напруженим для всіх учасників освітнього процесу: як вчителів i викладачів, так і для школярів, батьків та студентів. Через відсутність або недостатній досвід проведення дистанційного навчання та неоднозначну реакцію з боку уряду виникло багато проблем в навчанні та освіті загалом. За даними 
онлайн-опитувань щодо ведення дистанційного навчання в закладах загальної середньої освіти, проведених Державною службою якості освіти (ДСЯО) та освітнім омбудсменом вважаємо за доцільне наголосити на тому, що хоч ці опитування проводилися ще весною 2020 року, тобто в період жорсткого карантину, коли всі заклади були на дистанційному навчанні, більшість 3 проблем і досі є актуальними та практично невирішеними.

На жаль, в Україні наразі ще бракує практичних та методичних рекомендації щодо ефективної організації занять в умовах дистанційного навчання, а також інструментів, за допомогою яких викладачі мали б змогу обмінюватися набутим позитивним досвідом одні з одними. У дослідженні I. Блощинського зазначено, що поняття «дистанційне навчання» має не менше 30 термінів-елементів [1]. Серед наведених прикладів знаходимо і вживання терміна «дистанційне навчання» в ототожненні $з$ терміном «дистанційна освіта».

Дистанційне навчання розуміють також як: «технологію» [2]; «форму освіти», «цілеспрямований інтерактивний асинхронний процес», «комплекс освітніх послуг», «організацію освітнього процесу», «сукупність інформаційних технологій», «сходинку заочного навчання», «універсальну гуманітарну форму навчання», «електронний варіант очного або заочного навчання» [3]. На сайті МOH дистанційну освіту охарактеризовано як: можливість навчатися та отримувати необхідні знання віддалено від навчального закладу в будь який зручний час.

Важлива роль належить відкритим освітнім ресурсам (Open Educational Resources, OER), які існують у відкритому доступі або випущені за відкритою ліцензією, яка дозволяє їх безкоштовне використання та модифікацію третіми особами, [4] а також програмному забезпеченню користувацького інтерфейсу оскільки зростає роль і значення цифровізації в освіті та усіх галузях суспільного життя загалом. «Ці ресурси можуть бути у вигляді підручників, інтерактивних курсів, тестів, мультимедіа, програмного забезпечення та інших інструментів, які можуть бути використані у процесі навчання, що дозволяє вважати їх частиною (елементами) цифрового освітнього середовища» [4, С. 17]. Практика показує, що, враховуючи це, особливої актуальності набуває розробка та оцінка нового користувацького прототипу інтерфейсу («інтерфейс користувача») для порталів краудсорсингу (в процесі читання текстів 3 метою пошуку та виправлення помилок оцифрованого тексту, який спочатку був у друкованому паперовому вигляді. Зокрема, Койл (2006) вважає, що масова оцифровка газет, книг та інших старих текстів має на меті «... оцифрувати все або, в даному випадку, кожну книгу, коли-небудь надруковану» [5]. Протягом тривалого часу основною проблемою було створення нового прототипу користувальницького інтерфейсу який був би більш корисним, ніж користувальницький інтерфейс Connect TypeWright в плані продуктивності та задоволеності користувачів.

Ці аспекти пов'язані 3 теорією когнітивного навантаження. Когнітивне навантаження відноситься до психічних ресурсів, якими людина володіє для вирішення проблем або виконання завдань у певний час. 3 точки зору користувальницьких інтерфейсів, когнітивне навантаження, накладене 
користувальницьким інтерфейсом, - це кількість розумових ресурсів, необхідних для роботи системи.

Наші дослідження вказують на те, що порушення звичайного режиму навчання, пов'язане з пандемією коронавірусу COVID-19, негативно вплинуло на навчання студента. Вважаємо, що ефективність студентського навчання скоротилося майже до 19\% від стандартного відхилення.

Вважаємо доцільним виокремити загальні наслідки дистанційного навчання. Більшість викладачів не отримали жодних рекомендацій щодо методики проведення дистанційного навчання або навчання за допомогою освітніх он- лайн інструментів. Безумовно, для них стали б у пригоді поради щодо того, як пояснювати новий матеріал, давати зворотній зв'язок, тренувати навички, оцінювати прогрес та визначати тривалість уроків в умовах дистанційного навчання. Великою проблемою, яка заважала ефективній роботі не тільки вчителів, а й здобувачів освіти, стала відсутність необхідного обладнання вдома.

Перехід на дистанційне навчання виявив нерівність, яка існує між учнями сіл i міст у доступі до інформаційних ресурсів: понад 4 мільйони українців мешкають у селах, де немає якісного фіксованого Інтернету. Велика частина опитаних наголосила на тому, що вони не забезпечені гаджетами для продуктивної організації навчання. За даними опитування, більшість учнів використовували мобільні телефони, ймовірно смартфони, для дистанційного навчання. Натомість менше користуються ноутбуком та стаціонарним комп'ютером. Водночас не всі завдання можливо виконувати на телефоні. На сьогодні немає об'єктивних даних щодо того, як карантин вплинув на навчальні результати здобувачів освіти. Немає поки що і можливості встановити, як карантин вплинув на рівень знань учнів та студентів навчальних закладів освіти, але одне залишається незаперечним що пандемія внесла зміни в різні сфери життя, а наслідки карантину ми зможемо проаналізувати лише згодом.

Нами виявлено, що викладачі, які мали попередній досвід викладання в Інтернеті, майже компенсували втрати внаслідок пандемії. Інші інноваційні педагогічні методи мали менший, але все ще значний позитивний вплив.

Незважаючи на втрати внаслідок зривів, викликаних пандемією, наші результати залишають нас оптимістичними щодо майбутнього навчання студентів. По-перше, багато вчителів шкіл та викладачів університетів набули досвіду викладання в Інтернеті протягом весни 2020 року - і по нинішній час. Це означає, що втрати ефективності в навчанні учнів та студентів не повинні бути такими великими протягом наступних періодів навчання у $2021-2022$ навчальному році, якщо тенденція продовжуватиметься і коли учні та студенти знову будуть змушені навчатись через Інтернет. По-друге, виявився той факт, що «слабші у навчанні» студенти не зазнали непропорційного впливу, $\epsilon$ позитивним результатом. По-третє, деякі інноваційні методи викладання та діяльність у малих групах мають низькі витрати на впровадження та можуть значно покращити навчання студентів використовуючи засоби Інтернету. 
Висновки. Незважаючи на те, що ми щодня користуємося різноманітними гаджетами, швидко обмінюємося потрібною інформацією, змінюємо провайдера або мобільного оператора 3 метою отримання високошвидкісного Інтернету, сучасні здобувачі освіти та багато педагогічних працівників виявилися не готовими до впровадження єдиної активної технології дистанційного навчання. 3'ясувалося, що недостатньо мати цілодобовий доступ до дистанційних навчальних дисциплін та інші переваги такого навчання, які, безперечно, присутні. Необхідною $є$ емоційна взаємодія 3 викладачем, консультації та роз'яснення виконання завдань, навички планування й організації освітньої діяльності, самоосвіти, таймінгу та ін.

Стосовно вищої школи та науки то в перспективі актуальним залишається організація та поширення практики перманентних широкомасштабних перспективних досліджень, технологічних розробок та інноваційних ринків на основі інноваційних досягнень української науки.

Отже, дистанційне навчання є актуальною освітньою технологією XXI ст. Дистанційне навчання має ряд переваг та недоліків, перелік яких або поновлюється, або принципово змінюється. Змінюються i ролі здобувача освітнього процесу та педагогічного працівника. На нашу думку, після закінчення карантину у зв'язку із поширенням коронавірусу COVID-19 різні форми організаційні форми дистанційного навчання необхідно буде підтримувати, втілювати та розвивати.

\section{Лimepamypa:}

1.Блощинський I. Сутність та зміст поняття «дистанційне навчання» в зарубіжній та вітчизняній науковій літературі [Електронний ресурс] / І.Блощинський // Вісник Національної академії Державної прикордонної служби України. Педагогічні науки. - 2015. - № 3. - С. 23 26. - Режим доступу: http://nbuv.gov.ua/UJRN/Vnadps_2015_3_4

2.Павленко О. Використання дистанційного навчання в вищих навчальних закладах [Електронний ресурс] / О.Павленко // Вісник Національного технічного університету України «Київський політехнічний інститут». Філософія. Психологія. Педагогіка. - 2007. - № (21). С. 78-83. - Режим доступу: https://novyn.kpi.ua/2007-3-2/16_Pavlenko.pdf.

3.Красний С. І. Відкрита освіта і дистанційне навчання : навч. посіб. [Електронний pecypc] / C.I. Красний / - Київ: ДВНЗ «УН-т менеджменту освіти» НАПН України, 2016. - 61 с. - Режим доступу: http://www.dut.edu.ua > uploads

4.Антощук С.В. Відкриті веб-ресурси в цифровому освітньому середовищі. Відкрита та дистаниійна освіта : від теорії до практики : зб. матеріалів III Всеукр. електронної наук.практ. конф., м. Київ, 18 вересня 2018 р. Київ, 2018. С.17-18.

5. Coyle, K. (2006) Mass Digitization of Books, The Journal of Academic Librarianship, 32: 6, P. 641-645.

6. Yacoub, S, Burns, J, Faraboschi, P, Ortega, D, Peiro, J.A. and Saxena, V. (2005) Document Digitization Lifecycle for Complex Magazine Collection, Proceedings of the 2005 ACM Symposium on Document Engineering, P. 197-206.

\section{References:}

1.Blotch shinskiy, I. (2015). Sutnist ta zmist poniattia distantsiyne navthannia v zarubijniy ta vitchiznianiy naukoviy literature [The essence and content of the concept of "distance learning" in foreign and domestic scientific literature].Kyiv [in Ukrainian]. 
2. Pavlenko, O. (2007). Vikoristannia distantsiynogo navthannia $\mathrm{v}$ visstchich navtchalnich zakladah [Use of distance learning in higher education institutions].Visnik Natsionalnogo teknitchnogo universitetu Ukraini «Kyivskiy polithechnitchniy institut» - Bulletin of the National Technical University of Ukraine "Kyiv Polytechnic Institute", № (21), 78-83. Retrieved from https://novyn.kpi.ua/2007-3-2/16_Pavlenko.pdf [in Ukrainian].

3.Krasniy, S.I. Vidkrita osvita i distantsiyne navthannia [Open education and distance learning].Kyiv: Universytet menedjmentu osviti. Retrieved from ftp:// http://www.dut.edu.ua > uploads [in Ukrainian].

4. Antoshchuk, S.V. (2018). Vikriti web-resursi u tsifrovomu osvitniomu eredowyshchi [Open web resources in the digital educational environment]. Kyiv [in Ukrainian].

5.Coyle, K. (2006) Mass Digitization of Books, The Journal of Academic Librarianship, 32: 6, P. 641-645.

6. Yacoub, S, Burns, J, Faraboschi, P, Ortega, D, Peiro, J.A. and Saxena, V. (2005) Document Digitization Lifecycle for Complex Magazine Collection, Proceedings of the 2005 ACM Symposium on Document Engineering, P. 197-206. 